\title{
THE ROLE OF LOCAL CONTRACTING AUTHORITIES IN GREEN PURCHASING OF PAPER PRODUCTS
}

\author{
POSTAVENIE MIESTNYCH SUBJEKTOV \\ VEREJNEJ SPRÁVY \\ PRI ZELENOM VEREJNOM OBSTARÁVANÍ \\ PAPIEROVÝCH PRODUKTOV
}

\author{
Tomáš MALATINEC - Ján KYJOVSKÝ*
}

\section{Introduction}

In order to completely exploit the potential of Public Procurement to achieve the Europe 2020 objectives for smart, sustainable and inclusive growth, the environmental, social and innovative procurement also has to have a role in the EU. Green Public Procurement (GPP) currently represents a voluntary tool of public administration to support eco-innovations and sustainable economy. Public entities make up a significant group of consumers of products, and through their public contracts they are able to positively influence sustainable consumption. GPP can help stimulate a critical mass of demand for more sustainable goods and services which otherwise would be difficult to get onto the market ${ }^{(1)}$.

European Commission. (2019). Green Public Procurement. Available online: https://ec.europa.eu/environment/gpp/index_en.htm.

\section{Abstract (EN)}

Green Public Procurement is currently a voluntary instrument to promote Sustainable Consumption and Production and Sustainable Industrial Policy. Surveys in this field help to understand how individual States, Public Authorities and Organizations, are approaching this voluntary instrument and thus how far they support Eco-Innovations and Sustainable Economy. Our survey focuses on mapping of units of local self-governments in the Slovak Republic that carried out Green Public Procurement in the category of paper products through the Electronic Contracting System (ECS) in 2017. We consider local self-government units to be major consumers of paper products, especially because of their extensive administration, what makes them a target group to promote the use of Green Public Procurement in a given category in practice. The total number of contracts awarded through the ECS in 2017 was 471 . As the results show, the share of Green Public Procurements in the total number of Public Procurements in the Slovak Republic in 2017 was not satisfactory. In order to improve the situation, it is necessary to further deepen the targeted dissemination of examples of good practice in Green Public Procurement.

\section{Keywords (EN)}

green public procurement, local self-governments, paper products
Benefits of Green Public Procurement are visible in particular in meeting specific environmental objectives and tasks (e.g. energy efficiency, conservation of natural resources, reducing $\mathrm{CO}_{2}$ emissions); improving social and health conditions (e.g. improving quality of life, health protection); saving costs; strengthening the confidence of citizens, entrepreneurs and society toward public administration; promoting innovation; supporting the development competitive environmental goods and services; and expanding the market for such products. ${ }^{(2)}$

\footnotetext{
2) Ministry of Environment. (2019). Strategy of the Environmental Policy of the Slovak Republic until 2030. Available online: https: // www.minzp.sk/files/iep/greener_slovakia-strategy_of_the_environmental_policy_of the_slovak_republic_until_2030.pdf.
}

\section{Abstrakt (SK)}

Zelené verejné obstarávanie v súčasnosti predstavuje dobrovolný nástroj na podporu udržatel'nej spotreby a výroby a udržatelnej priemyselnej politiky. Prieskumy orientované na túto oblast' pomáhajú porozumiet,' ako jednotlivé štáty, orgány a organizácie, $v$ súčasnej dobe pristupujú k napíñaniu tohto dobrovolného nástroja, a teda v akej miere podporujú eko-inovácie a udržatelnú ekonomiku. Náš prieskum sa zameriava na mapovanie jednotiek samospráv v Slovenskej republike, ktoré realizovali zelené verejné obstarávanie v roku 2017 v kategórií papierové produkty prostredníctvom Elektronického kontrakčného systému (EKS). Jednotky samospráv považujeme za významných spotrebitelov papierových produktov, najmä vzhladom na ich rozsiahlu administratívu, čo z nich vytvára cielovú skupinu na podporu využívania zeleného verejného obstarávania v danej kategórii v praxi. Celkový počet zadaných zákaziek prostredníctvom Elektronického kontrakčného systému (EKS) v roku 2017 bol 471. Ako to z prieskumu vyplýva, podiel zelených verejných obstarávaní na celkovom počte verejných obstarávaní v Slovenskej republike v roku 2017 nebol uspokojivý. Za účelom zlepšenia danej situácie je preto potrebné nadalej prehlbovat' cielené šírenie príkladov dobrej praxe zeleného verejného obstarávania vo verejnej sfére.

\section{Klưčové slová (SK)}

zelené verejné obstarávanie, miestna územná samospráva, papier

\footnotetext{
* Technical University of Košice, Slovakia
} 
Green Public Procurement can bring other benefits depending on sector of implementation. ${ }^{(3)}$

The EU Public Procurement Directives ${ }^{(4),(5)}$, emphasize the application of strategic public procurement, which includes environmental, social and innovative elements and the promotion of small and medium-size enterprises. It is a horizontal tool of public procurement.

Act on Public Procurement ${ }^{(6)}$ allows contracting authorities to develop a description of the object of the contract on the basis of performance and functional requirements, which may include environmental characteristics; technical requirements must be determined on a way to make clear all of the conditions and circumstances relevant to the elaboration of the offer. Contracting authorities may determine specific conditions relating to the performance of a contract. These specific conditions may include economic, social, environmental, innovation-related or employment-related aspects. The contracting authority may require the submission of a certificate certifying compliance with the requirements of the Environmental Management System Standards issued by an independent body.

According to the Strategy for the Environmental Policy of the Slovak Republic ${ }^{(7)}$, Green Public Procurement will cover at least $70 \%$ of the total value of all public procurements by 2030 . Green Public Procurement will be mandatory for the central government, self-governing regions and cities - initially only for selected product groups, later it will gradually expand to achieve the target by 2030. The Electronic Public Procurement will ensure simple and transparent procurement and monitoring of the Green Public Procurement.

The aim of the article is to evaluate the practice of contracting authorities in the implementation of Green Public Procurement in the group of paper products with emphasis on the position of local subjects of public administration.

\section{Theoretical background}

The concept of Green Public Procurement increases in promotion at the level of the European Union and its Member States. Green Public Procurement is an important tool for achieving environmental policy objectives, which are in connection with climate change, use of natural resources and sustainable consumption and production, especially seeing the importance of public sector spending on goods and services in Europe. ${ }^{(8)}$

Based on World Bank data, the EU28 average expenditures

(3) Yang, S., Su, Y., Wang, W., Hua, K. (2019). Research on Developers' Green Procurement Behaviour Based on the Theory of Planned Behaviour In: Sustainability. 11 (10). p. 1-23. Doi: 10.3390/ sull102949.

(4) EU Directive No. 2014/24/EU on public procurement.

(5) EU Directive No. 2014/25/EU on procurement by entities operating in the water, energy, transport and postal services sectors.

(6) Act No. 343/2015 Coll. on Public Procurement and on Amendments to certain Laws as amended.

(7) Ministry of Environment. (2019). Strategy of the Environmental Policy of the Slovak Republic until 2030. Available online: https: // www.minzp.sk/files/iep/greener_slovakia-strategy_of_the_environmental_policy_of_the_slovak_republic_until_2030.pdf.

(8) European Union. (2016). Buying green! A handbook on green public procurement. $80 \mathrm{p}$. Luxembourg, Publications Office of the European Union. ISBN: 978-92-79-56848-0. on goods and services of public sector have been around 20\% with a slight downward trend since the crisis in 2007-2008. It should be noted, that it is mostly the consumption with a significant impact on the environment. At the same time in this context we are able to state that public sector has an important role to play in creating sustainable consumption. Public authorities have the potential to change the direction of overall production and consumption by promoting environmentally friendly products and services. ${ }^{(9)}$

We observe that GPP enjoys increased attention of leading institutions of the EU in recent years.

The European Commission has published voluntary EU GPP criteria for 19 product groups. "Core GPP criteria address the most significant environmental impacts and are designed to be used with minimum additional verification effort or cost increases. Comprehensive GPP criteria are intended for use by authorities who seek to purchase the best environmental products available on the market and may require additional administrative effort or imply a certain cost increase as compared to other products fulfilling the same function". (10)

Paper products are one of the product groups, which environmental criteria are set for.

„Paper consumption is at unsustainable levels and globally it is steadily increasing. The industry has substantial climate change impacts, from its raw material sourcing in forests, through production, to the end of life of its products". ${ }^{(11)}$ The most important environmental aspects of copying and graphic paper are related to pulp and paper production. The pulp and paper industry is one of the world's biggest polluters. They are the following:(12)

- "Industrial logging linked to the paper industry is responsible for the substitution of functioning ecosystems with fast-wood plantations which can lead to a loss of biodiversity, disruption of local water cycles, loss of soil productivity and increased risk of pests and diseases.

- In pulping processes, sulphur compounds and nitrogen oxides are emitted to the air, and during pulp bleaching, chlorinated and organic compounds and nutrients are discharged to the wastewaters.

- The production process of paper, especially when mainly based on virgin fibre is associated with high levels of water and energy consumption.

- Pulp manufacture generates large quantities of solid waste, the most relevant of which are wood waste, pulp screening rejects and the sludge generated during wastewater treatment."

GPP should bring positive benefits when contracting authorities will implement procurement of paper based on post-consumer recovered paper fibres (recycled paper) or paper from

(9) Fuentes-Bargues, J. L. et al. (2019). Green Public Procurement at a Regional Level. Case Study: The Valencia Region of Spain. In: International Journal of Environmental Research and Public Health. 16 (16). 24p. Doi: 10.3390/ijerph16162936.

(10) European Commission. (2019). Green Public Procurement. Available online: https://ec.europa.eu/environment/gpp/index_en.htm.

(11) Environmental Paper Network. (2018). The State of the Global Paper Industry. 90 p. Available online: https://environmentalpaper. org/wp-content/uploads/2018/04/StateofTheGlobalPaperIndustry2018_FullReport-Final.pdf.

(12) European Commission. (2019). Green Public Procurement. Available online: https://ec.europa.eu/environment/gpp/index_en.htm. 
legally and sustainably harvested wood, procurement of paper produced through processes characterised by low energy consumption and emissions and will avoidance of certain substances in paper production and bleaching. ${ }^{(13)}$

Several studies are devoted to assessing the status quo of Green Public Procurement extension and the potential impacts of Green Public Procurement in different sectors and countries. ${ }^{(14)}$

Renda ${ }^{(15)}$ highlights the results of studies on how the EU countries use environmental criteria when awarding contracts. Finland makes the most use of it, which defines environmental criteria in $80 \%$ of all Public Procurements. The worst situation is in countries, where GPP does not even cover $20 \%$ of Public Procurements. Countries with such unsatisfactory results include: Bulgaria, Slovakia, Greece, Ireland, France and others.

GPP has been also considered by academic and practitioners as a tool useful to promote circular economy. ${ }^{(16)}$

In order to support positive impacts of GPP, organizations should foster a green identity by promoting pro-environmental values through training programs. ${ }^{(17)}$

However, Green Public Procurement does not appear to be a useful tool only for the public sector. As the results show of the Gosh's study ${ }^{(18)}$, the use of green criteria in procurement had a positive impact on all observed indicators of selected enterprises. On the other hand, we have to add, that the study worked with a relatively small sample, and focused only on the manufacturing.

\section{Methodology}

The survey was carried out in 2019. The specifically created database contains data on 471 public procurements of paper products realized through the Electronic Contracting System (ECS) in 2017. The ECS is an information system of public administration and it is a tool for fully automated placement of orders. The ECS is central trading place obligatory for public procurement and voluntary for anyone, who registers for free. The ECS supports efficiency, effectiveness, removal of admin-

(13) European Commission. (2008). Copying \& graphic paper, Green Public Procurement Product Sheet - Training Toolkit.

(14) Piga, G., Tatrai, T. (2016). Public Procurement Policy. Routledge, New Yourk. 229 p. ISBN 978-1-138-92150-4

${ }^{(15)}$ Renda, A. et al. (2012). The Uptake of Green Public Procurement on the EU27. CEPS, Submitted to the European Commission, DG Environment, Brussels. In: Fuentes-Bargues, J. L. et al. (2019). Green Public Procurement at a Regional Level. Case Study: The Valencia Region of Spain. In: International Journal of Environmental Research and Public Health. 16 (16). 24p. Doi: 10.3390/ijerph16162936.

(16) Marrucci, L., Daddi, T., Iraldo, F. (2019). The integration of circular economy with sustainable consumption and production tools: Systematic review and future research agenda In: Journal of Cleaner Production. 240 (10). Doi: 10.1016/j.jclepro.2019.118268.

(17) Al Nuaimi, B., Khan, M. (2019). Public-sector green procurement in the United Arab Emirates: Innovation capability and commitment to change In: Journal of Cleaner Production. 233 (1). p. $482-$ 489. Doi: 10.1016/j.jclepro.2019.06.090.

(18) Gosh, M. (2018). Determinants of green procurement implementation and its impact on firm performance. In: Journal of Manufacturing Technology Management. 30 (2). p. 462-482. Doi: 10.1108/ JMTM-06-2018-0168. istrative burden, transparency and elimination of corruption behaviour.

The studied product group contains the following CPV codes:

- 30197620-8 writing paper,

- 30197630-1 printing paper,

- 30197642-8 photocopier paper and xerographic paper,

- 30197643-5 photocopier paper,

- 30197644-2 xerographic paper,

- 30197640-4 self-copy or other copy paper.

The order description includes:

- name and registered office of the public contracting authority,

- name and registered office of the contractor,

- number of tenders submitted,

- the best price of delivery,

- information, whether at least one environmental criterion established for paper products was included.

The environmental criteria were classified as follows:

- public procurement of paper made from recovered paper fibres (recycled paper) or paper from legally and sustainably harvested wood,

- public procurement of paper produced by processes with low energy consumption and emissions,

- avoidance of certain substances in paper production and bleaching.

The aim of the analysis is, in particular, to identify the number of Green Public Procurement and Public Entities, which implemented these contracts in the given product group through Electronic Contracting System in 2017.

\section{Results}

The results of our survey show, that in 2017 - 471 (Fig.1) public procurements were carried out in product group paper products (CPV codes: 30197620-8, 30197630-1, 30197642-8, 30197643-5, 30197644-2 a 30197640-4) using the Electronic Contracting System (ECS). Public contracting authorities procured paper products through ECS with a total value of EUR $1,697,454.21$, what is a few tens of per cent increase compared to previous years. The average contract value is EUR 3,603.94 and the median value is EUR 900.00.

Compared to the total number of procurements in 2017, only 42 (8.92\%) were executed as green tenders. This means, that only in 42 cases contracting authorities included the environmental criteria proposed by the European Commission for this product group in the procurement process. It means contracting authorities make use of the possibility of procuring paper products meeting the environmental criteria in a relatively small extent. In order to increase the share of green procurement in paper products, it is necessary to support the motivation of contracting authorities and to implement targeted interventions to raise awareness of the beneficial effects of using green public procurement of paper products.

Environmental criterion - public procurement of paper 

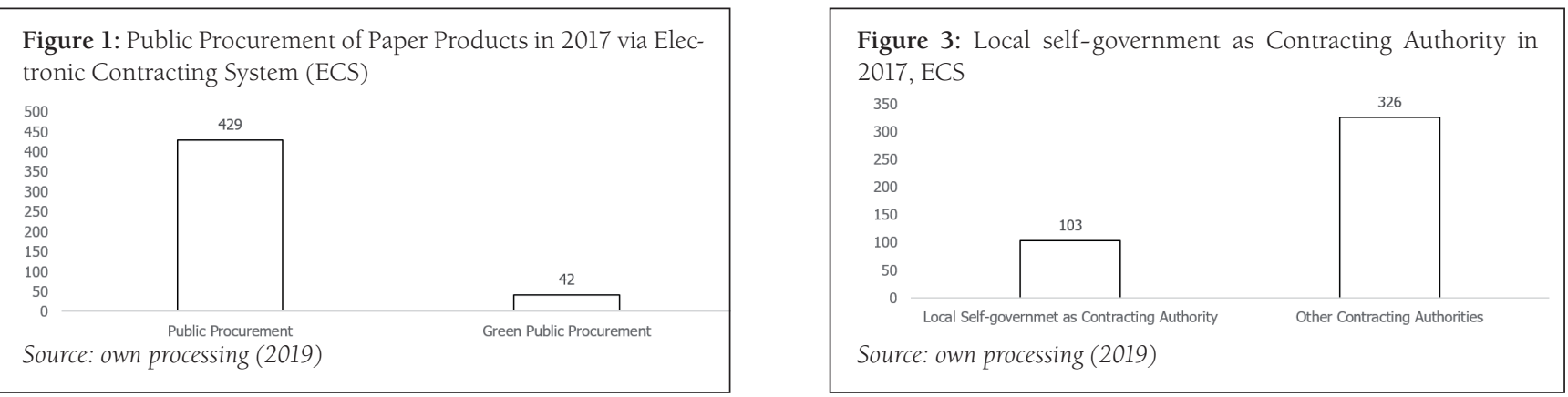

Figure 2: Spatial Allocation - Green Purchasing of Paper products in 2017 (unique values) via ECS

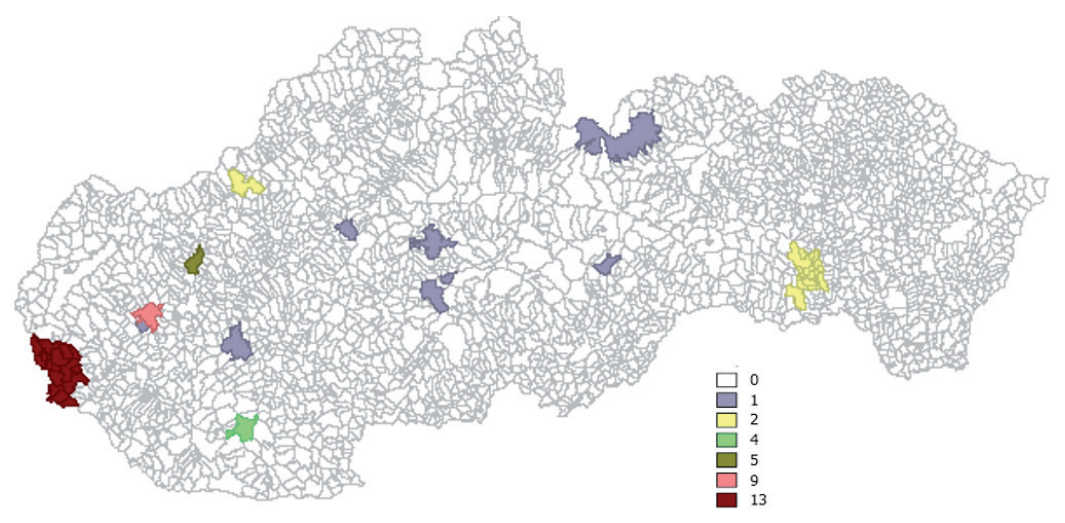

Source: own processing (2019)

made from recovered paper fibres (recycled paper) or paper from legally and sustainably harvested wood was used in 31 public contracts. Environmental criterion - avoidance of certain substances in paper production and bleaching was used in 22 public contracts. Environmental criterion - public procurement of paper produced by processes with low energy consumption and emissions was not used even once.

In the next section, we focused on the identification of administrative areas, in which the contracting authorities carried out green contracts to procure paper products via Electronic Contracting System in 2017. We are talking about the following administrative areas: Banská Bystrica, Bratislava, Hrnčiarovce nad Parnou, Košice, Nitra, Nové Zámky, Pieštany, Prievidza, Revúca, Vysoké Tatry, Trenčín, Trnava, Zvolen - these are mainly district towns (of which 6 are regional towns). Based on the spatial distribution, we cannot adopt conclusion, that contracting authorities prefer to carry out Green Public Procurement on the basis of their allocation. However, the results show, that there is a specific target group of entities (district towns) that could be supported to use the concept of Green Public Procurement more often, and thus they could contribute to developing the supply of products, which meet the environmental criteria.

Municipalities and towns (units of self-government) executed $103(21.87 \%)$ contracts of the total number of public contracts to procure paper products using the Electronic Contracting System in 2017 (Fig. 3). Based on the results, it can be concluded that municipalities and towns are an important group of contracting authorities of paper products, and therefore they are also important consumers. The group of mu- nicipalities and towns, which include 2890 entities (Statistical Office of the Slovak Republic, 2019) in the position of contracting authority has a significant potential to increase the share of green contracts accomplished in economic practice at the local level in the Slovak Republic. Municipalities and towns should be more involved in finding and implementing environmentally appropriate solution. Green Public Procurement should become an important part of municipal environmental policy. They together could contribute to the cumulative positive effect of this green concept.

In addition to local self-government units - central government units, budgetary organizations, contributory organizations and universities were important contracting authorities in the paper product group, either.

An important finding is that out of the total number of public procurement of paper products carried out by local self-government units through the Electronic Contraction System in 2017, only one (Fig. 4) contract was accomplished as a green contract, what means it contained environmental criteria for the product group of paper products. This contract was realized by the city district of Bratislava - Nové Mesto. The contract was worth EUR 14,350.00

The conclusion is, that Green Public Procurement of paper products carried out by public contracting authorities, which include municipalities and towns, was not used at the desired level. A comparison of the average number of offers submitted under green procurement and those, in which the contracting authorities did not incorporate the environmental criteria of the paper products into the contract shows, that under green contracts, the average number of offers submitted was higher 


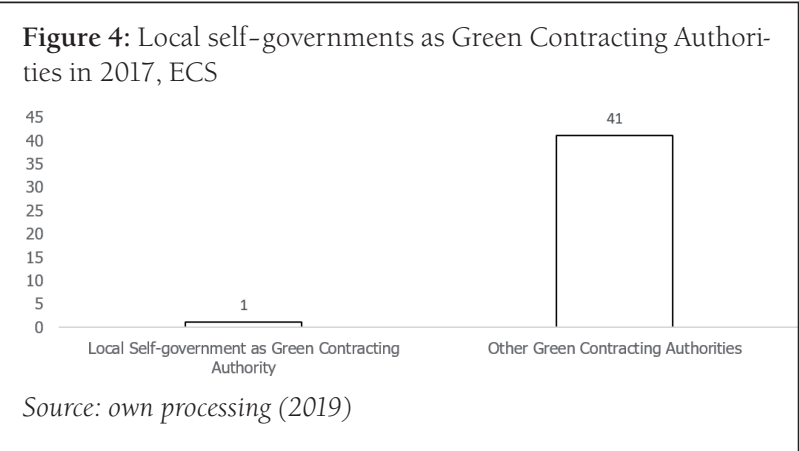

Figure 5: Average Number of Offers in 2017, ECS

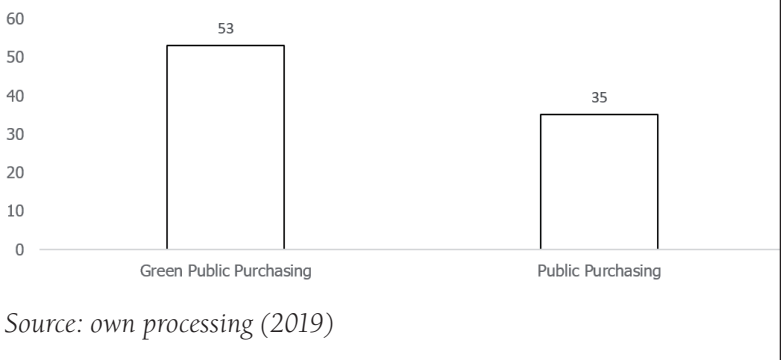

by 18 (Fig. 5). At the same time, this fact supports the achievement of the best possible price for the contracting authority, because the higher number of offers submitted increases the competition of suppliers.

However, the results of the survey point out a significant role of public universities as contracting authorities of Green Public Procurement of paper products. This makes public universities as a good example of good practice in green procurement. There is no doubt that public universities belong to major consumers of paper products as well as local public authorities.

Of the total number of public contracts, public universities acted as contracting authorities in 40 procurements, what represents $8.49 \%$ (Fig. 6). Green Public Procurement was carried out in 11 contracts (Fig. 7). This implies, that public universities are another target group suitable for interventions to promote Green Public Procurement. It is testified by their activity in meeting environmental criteria in the area of procurement of paper products, especially in the phase of voluntary application of Green Public Procurement to this type of product group.

Results of the survey point to the use of Green Public Procurement of paper products procured via Electronic Contraction System in 2017. They enable public policy makers to evaluate the current situation, make informed decisions and identify appropriate target groups of entities in order to support the implementation of Green Public Procurement in the public sector

\section{Conclusion}

In the survey, which was carried out in 2019, we focused mainly on identifying local self-government units (towns/municipalities) that implemented Green Public Procurement of paper products via Electronic Contracting System in 2017. We con-

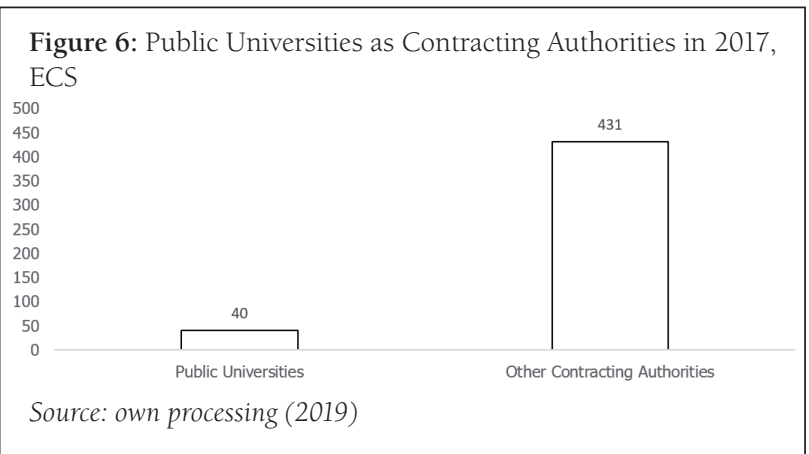

Figure 7: Public Universities as Green Contracting Authorities in 2017, ECS

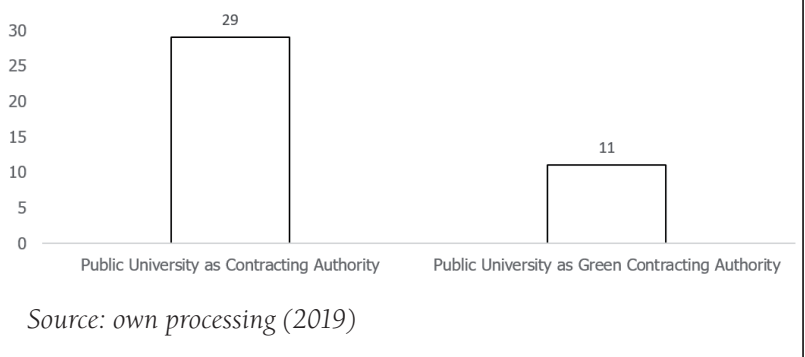

sider local self-government units as major consumers of paper products and thus a potential and important target group to promote the use of Green Public Procurement of paper products in practice.

The results of the survey show that out of the total number of public contracts for paper products in 2017 (471), environmental criteria proposed by the European Commission for the group of paper products were used within 42 (8.92\%) public contracts. Out of the total number of contracts executed, local self-government units accounted for 103 contracts (21.87\%), of which only 1 was executed as Green Public Procurement. Spatial distribution of green contracts for paper products realized via ECS in 2017 does not allow to identify more significant preferences for the implementation of green contracts, e.g. in more developed regions. However, we can conclude that entities who carried out Green Public Procurement of paper products were allocated in towns.

The results also show the significant role of public universities in the Green Public Procurement of paper products via Electronic Contraction System in 2017. Public universities accomplished 40 contracts $(8.49 \%)$ in 2017,11 of them were executed as Green Public Procurement (27.50\%). The results show, that local self-government units (towns/municipalities) did not favour the possibility to include the EU environmental criteria in the public procurement of paper products accomplished via ECS in 2017.

We consider as a slightly unsatisfactory result that all the contracts awarded via ECS in 2017 for the group of paper products used the lowest price as the selection criterion, despite the fact, that Slovak legislation allows the selection based on the best value for money selection criterion, in which contracting authority could consider qualitative, environmental and social aspects related to the subject of the contract.

The results show the use of Green Public Procurement in 
economic practice. On the other hand, it should be pointed out, that the absence of green criterion in the product specification when awarding a public contract does not automatically mean, that the product supplied does not meet the criteria of environmentally friendly product. Nowadays, many of paper products producers supply onto the market goods, that have been produced with little environmental footprint. They thus respond to the efforts of the European Union to create Sustainable Consumption and Production and Sustainable Industrial Policy. On the other hand, this cannot be seen as an argument, which relies the contracting authorities of their responsibility to try to increase the share of Green Public Procurements. After all, in general suppliers respond to consumers' needs, and not vice versa. If there will not be any improvement in the future, we cannot expect increased interest from suppliers to supply environmentally friendly products, which in the short term can be associated with higher costs.

In order to improve the situation, it is necessary to support tailor-made dissemination of good practices in Green Public Procurement, particularly in relation to municipalities and towns that have the potential to make more effective use of Green Public Procurement.

\section{References}

1. AL NUAIMI, B. KHAN, M. (2019). Public-sector green procurement in the United Arab Emirates: Innovation capability and commitment to change In: Journal of Cleaner Production. 233 (1). p. 482-489. DOI: 10.1016/j.jclepro.2019.06.090

2. FUENTES-BARGUES, J. L. et al. (2019). Green Public Procurement at a Regional Level. Case Study: The Valencia Region of Spain. In: International Journal of Environmental Research and Public Health. 16 (16). 24p. Doi: 10.3390/ijerph16162936

3. GOSH, M. (2018). Determinants of green procurement implementation and its impact on firm performance. In: Journal of Manufacturing Technology Management. 30 (2). p. 462-482. Doi: 10.1108/JMTM-06-2018-0168

4. ENVIRONMENTAL PAPER NETWORK. (2018). The State of the Global Paper Industry. 90 p. Available online: https://environmentalpaper.org/wp-content/uploads/2018/04/StateofTheGlobalPaperIndustry2018 FullReport-Final.pdf

5. EUROPEAN COMMISSION. (2008). Copying \& graphic paper, Green Public Procurement Product Sheet - Training Toolkit.

6. EUROPEAN COMMISSION. (2019). Green Public Procurement. Available online: https://ec.europa.eu/environment/gpp/index_ en.htm

7. EUROPEAN UNION. (2016). Buying green! A handbook on green public procurement. 80 p. Luxembourg, Publications Office of the
European Union. ISBN: 978-92-79-56848-0

8. MARRUCCI, L. - DADDI, T. - IRALDO, F. (2019). The integration of circular economy with sustainable consumption and production tools: Systematic review and future research agenda In: Journal of Cleaner Production. 240 (10). Doi: 10.1016/j. jclepro.2019.118268

9. MINISTRY OF ENVIRONMENT. (2019). Strategy of the Environmental Policy of the Slovak Republic until 2030. Available online: https://www.minzp.sk/files/iep/greener_slovakia-strategy_of_ the_environmental_policy_of_the_slovak_republic_until_2030.pdf

10. PIGA, G. - TATRAI, T. (2016). Public Procurement Policy. Routledge, New Yourk. 229 p. ISBN 978-1-138-92150-4

11. RENDA, A. et al. (2012). The Uptake of Green Public Procurement on the EU27. CEPS, Submitted to the European Commission, DG Environment, Brussels. In: Fuentes-Bargues, J. L. et al. (2019). Green Public Procurement at a Regional Level. Case Study: The Valencia Region of Spain. In: International Journal of Environmental Research and Public Health. 16 (16). 24p. Doi: 10.3390/ ijerph16162936

12. YANG, S., SU, Y., WANG, W., HUA, K. (2019). Research on Developers' Green Procurement Behaviour Based on the Theory of Planned Behaviour In: Sustainability. 11 (10). p. 1-23. Doi: 10.3390/sul1102949

\section{Legislation}

1. Act No. 343/2015 Coll. on Public Procurement and on Amendments to certain Laws as amended

2. EU Directive No. 2014/24/EU on public procurement

3. EU Directive No. 2014/25/EU on procurement by entities operating in the water, energy, transport and postal services sectors

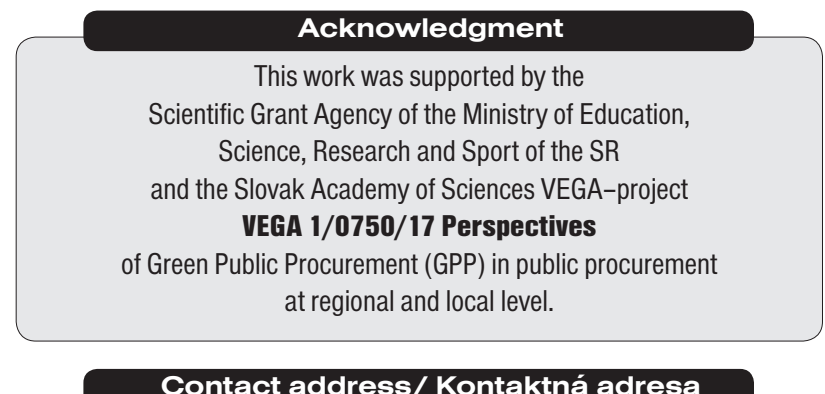

Mgr. Ing. Tomáš Malatinec, PhD.

Department of Regional Science and Management

Faculty of Economics, Technical University of Košice e-mail: tomas.malatinec@tuke.sk 